\title{
Geosmin contamination status of raw and treated waters in Sri Lanka
}

\author{
Sathya Ganegoda ${ }^{1}$, S.D.M. Chinthaka ${ }^{2}$ and Pathmalal M. Manage ${ }^{{ }^{*}}$ \\ ${ }^{I}$ Centre for Water Quality and Algae Research, Department of Zoology, University of Sri Jayewardenepura, Nugegoda. \\ ${ }^{2}$ Department of Chemistry, Faculty of Applied Sciences, University of Sri Jayewardenepura, Nugegoda.
}

Submitted: 18 May 2018; Revised: 05 December 2018; Accepted: 21 December 2018

\begin{abstract}
Off taste and odour in drinking water cause a serious issue in some parts of Sri Lanka and higher number of customer complaints is related to off taste and odour in treated water. Water sources are having diverse range of algae and cyanobacteria community and most of them produce chemical compounds like geosmin. A simple and sensitive modified method for the determination of earthy odorant geosmin in water was developed by headspace solid-phase micro extraction coupled with gas chromatography-mass spectrometry. Quantification of the geosmin contamination level in 22 drinking water sources (raw water bodies and water treatment plants) was carried out for the first time in Sri Lanka. Results revealed that $68 \%$ of the sampling locations exceed the human threshold level of geosmin $\left(5 \mathrm{ng} \mathrm{L}^{-1}\right)$. The concentration of geosmin in raw water bodies ranged from 7.825 to $10.929 \mathrm{ng} \mathrm{L}^{-1}$ whereas in treated water it ranged from 8.113 to $11.196 \mathrm{ng} \mathrm{L}^{-1}$. Geosmin concentrations in treated water were higher than in the respective raw water. Some taste and odour producing cyanobacteria and algae were identified and quantified in the same water bodies where geosmin was detected. Anabaena sp., Cylindrospermopsis sp., Microcystis sp., Oscillatoria sp. and Volvox sp. are the common cyanobacteria and algae in water bodies. Total taste and odour forming cyanobacteria and algae count have shown a significantly positive correlation with geosmin concentration $(\mathrm{p}<0.05)$. A significant positive correlation was found between geosmin and total phosphorus $(p<0.05)$, electrical conductivity $(\mathrm{p}<0.05)$ and $\mathrm{pH}(\mathrm{p}<0.05)$, factors that normally favour cyanobacterial growth.
\end{abstract}

Keywords: Cyanobacteria, gas chromatography-mass spectrometry, geosmin, headspace solid-phase micro extraction, taste and odour.

\section{INTRODUCTION}

The provision of adequate volumes of safe, clean drinking water to the world's growing population is a continual and increasing challenge for water authorities around the world. Although health aspects of water are the primary focus, consumers generally judge the quality of water by its aesthetic value. A common and recurrent problem in drinking water is the occurrence of taste and odour (T\&O) producing compounds (Jiang et al., 2007). T\&O compounds are the cause of most consumer complaints and rejections specially related to potable water where flavour and smell of the water is the only measure of water quality for the end-user (AwwaRF, 2000). Geosmin (trans-1, 10-dimethyl-trans -9-decalol) is one of the most common chemicals which produces $T \& O$ in water, which produces an earthy odour (Jiang et al., 2007). Secondary metabolites of two groups of aquatic microorganisms; cyanobacteria and actinomycetes have been considered to be the main cause of earthy taints in drinking water (Zuo et al., 2009; Ding et al., 2014a). Geosmin is a tertiary alcohol first isolated in 1965 (Mcdowall, 2008). Often lakes and reservoirs are contaminated with geosmin and other odourants (Ding et al., 2014b) where people can smell the odour in water samples. Human threshold level for geosmin is found to be in the range of 5 to $40 \mathrm{ng} \mathrm{L}^{-1}$ and although there are very low levels of geosmin present in water, consumers still can taste an unpleasant earthy flavour in water.

*Corresponding author (pathmalal@sjp.ac.lk; (BD https://orcid.org/0000-0002-2014-2060) 
Geosmin is a semi volatile compound and is produced by algae, cyanobacteria and actinomycetes and has a stable chemical structure (Sorial \& Srinivasan, 2011). Therefore, conventional water treatment processes such as aeration, coagulation, flocculation, boiling, chlorination and filtration have failed to reduce the levels below human threshold (Sorial \& Srinivasan, 2011). Hence, this has become a challenge to conventional water treatment processes. Odour may develop downstream of water treatment as a result of heterotrophic biological activity in distribution pipes and sand bed filtration post treatments. Production of geosmin has been documented in several studies (Ju"ttner \& Watson, 2007). For example, heterotrophic eukaryotes such as fungi, which colonise biofilms in activated filters and distribution pipes can generate potent musty-smelling metabolites such as trichloroanisol (Ju"ttner \& Watson, 2007). According to Ju"ttner and Watson (2007), geosmin in treated drinking water was traced to the disturbance of thick biofilms that had developed on the pipe surfaces of a distribution system from a groundwater-supplied treatment plant. After a change in water treatment process in the plant to remove iron from the iron-rich source water, the biofilms degraded and sloughed off, releasing high levels of geosmin, leading to consumer complaints. In another case, biological activity in poorly maintained filtration media was considered to be the most likely cause of high geosmin levels downstream of filter beds in a small rural treatment plant (Ju"ttner \& Watson, 2007). Geosmin contamination in either raw or treated water certainly raises the issue of water rejection and complaints by consumers. A survey conducted in more than 800 utilities in the United States and Canada had found that $16 \%$ of the utilities experienced serious earthy odour problems, and that utilities spend an average of about $4.5 \%$ of their total treatment budget on earthy smell control (Tian, 2013). Therefore, water utilities around the world struggle to deal with the irregular pattern of appearance of these compounds in their source waters, which increases the treatment cost. The ability to reliably predict, confirm and counteract their occurrence would be important to water utilities and other branches of industry, such as aquaculture farms where these compounds can spoil entire harvests (Zuo et al., 2009, Jade \& Emilia 2013). According to $\mathrm{WHO}$, the provision of drinking-water that is not only safe but also acceptable in appearance, taste and odour (T\&O) is of high priority (WHO, 2011). Tap water with detectable T\&O may be perceived by the consumer as unsafe to drink although it adapts to the guideline for regulated constituents (Tian, 2013). More importantly this could lead to the use of water from sources that are less safe (WHO, 2011). Although neither the United States Environmental Protection Agency
(USEPA) nor the World Health Organization (WHO) has declared geosmin as a health hazard, geosmin can lead to acute health effects such as heat exhaustion and sunstroke, or chronic health effects such as kidney problems (Tian, 2013). Moreover, it is reported that toxins and geosmin frequently co-occurred indicating odour may serve as a warning that cyanotoxins are likely to be present (Chen et al., 2010). Many studies have been conducted in this field worldwide, but so far no studies have been published related to geosmin in Sri Lanka.

Climatic conditions around the world are changing such that more extreme events of flooding and drought, and a general increase in ambient temperatures are favouring both the occurrence and intensity of blue-green algae (cyanobacteria) blooms (Sethunga \& Manage, 2010; Cayelan et al., 2012). The increasing frequency and intensity of harmful cyanobacterial proliferation in water sources is a growing global issue (Preecea et al., 2017; Yatigammana \& Perera, 2017). Cyanobacteria blooms have been recognised as a nuisance in drinking water and aquaculture industries because some species produce potent odour compounds. When large numbers of cyanobacteria and bacteria flourish in a water body, $\mathrm{T} \& \mathrm{O}$ compound concentrations increase to levels above the human threshold and cause T\&O problems (Sethunga \& Manage, 2010; Idroos, 2015; Idroos et al., 2015). Earthy T\&O producing geosmin is one of the most frequently identified T\&O compounds associated with cyanobacterial blooms (Sethunga \& Manage 2010; Zamyadi et al., 2010). Several cyanobacterial species are potent producers of T\&O compounds and toxins and Watson et al. (2008) have documented the presence of geosmin producing cyanobacteria in surface water bodies. Anabaena circinalis, A. scheremetievi, Phormidium tenue, Pseudanabaena (planktonic), Oscillatoria $f$. granulata, O. simplicissima, O. curviceps, O. tenuis are found to be toxic and produce geosmin in source water (Izaguirre \& Taylor, 2007; Ju"ttner \& Watson, 2007; Ho et al., 2009; Sethunga \& Manage, 2010; Zamyadi et al., 2010; WHO, 2011).

In most parts of Sri Lanka, consumers receive treated and untreated water mainly from lakes, reservoirs and ponds, which are contaminated with algae and cyanobacteria. According to available literature on algae and cyanobacteria, in Sri Lanka almost all water sources used for drinking purposes have a high diversity of algae and cyanobacteria (Sethunga \& Manage 2010; Hettiarachchi et al., 2013; Hettiarachchi \& Manage 2014; Idroos et al., 2015) which are responsible for the production of chemicals such as geosmin (JICA, 2012). Further, seasonal cyanobacteria and algal blooms have been recorded in raw water bodies where water is used 
for drinking by the National Water Supply and Drainage Board (NWSDB) of Sri Lanka. Consumer complaints regarding earthy taste and odour show an increasing trend and this issue is serious among water consumers in North Central, Eastern, North East, North, Uva and southern part of the country (NWSDB, 2011).

Therefore, determination of contamination status by such compounds must be given priority to improve water treatment facilities and technology to safeguard drinking water. The present study was carried out to detect and quantify geosmin contamination levels in both raw water and treated water, covering 5 districts in Sri Lanka (Anuradhapura, Polonnaruwa, Ampara, Batticaloa and Trincomalee districts). These sampling locations were selected on the basis of available information from the NWSDB (unpublished data) where T\&O problems were prevalent. Further, all raw water bodies selected are used by the NWSDB to provide drinking water after treatment.

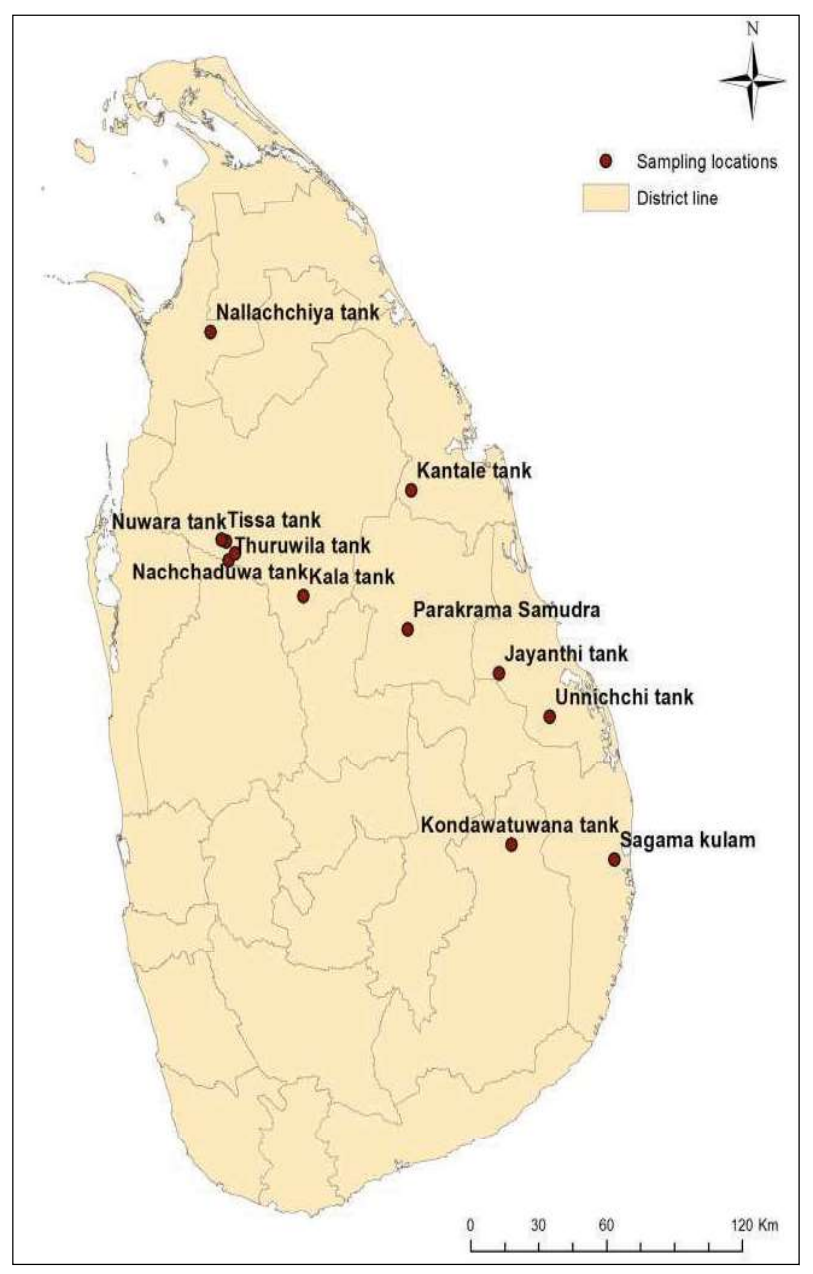

\section{METHODOLOGY}

\section{Materials}

Geosmin was purchased from Sigma Aldrich, USA and dissolved in deionised water to make a stock solution at a concentration of $200 \mu \mathrm{gL}^{-1}$. The solution was stored at $4{ }^{\circ} \mathrm{C}$ and used after dilution with deionised water. Molecular grade sodium chloride was obtained from Sigma Aldrich, USA.

Manual fiber assembly of solid-phase micro extraction (SPME) with an extraction fiber coated with stable flex divinylbenzene/ carboxen/ polydimethylsiloxane (DVB/CAR/PDMS) microfiber with film thickness $50 \mu \mathrm{m} / 30 \mu \mathrm{m}$ was purchased from Supelco (Tokyo, Japan).

\section{Sample collection and preparation to detect geosmin}

A volume of $10 \mathrm{~mL}$ of surface water from raw water bodies and $10 \mathrm{~mL}$ of treated water from water treatment plants (WTPs) (Jayanthi wewa, Sagama tank, Kondawatuwana tank, Unnichchai tank, Kantale tank, Nachchadoowa tank, Kala tank, Nallachchiya tank, Thuruwila tank, Tissa tank, Nuwara tank and Parakrama Samudraya)

\begin{tabular}{lll}
\hline Collection source & District & Province \\
\hline Jayanthi tank & & \\
Jayanthi WTP & & \\
Sagama tank & & \\
Sagama WTP & Ampara & \\
Kondawatuwana tank & & \\
Kondawatuwana WTP & & \\
Unnichchai tank & Trincomalee & \\
Unnichchai (Wavnativ) WTP & \\
Kantale tank & Batticaloa & \\
Kantale WTP & \\
Nachchadoowa tank & \\
Kala tank & \\
Kala WTP & \\
Nallachchiya WTP & \\
Thuruwila tank & \\
Thuruwila WTP & \\
Tissa tank & Anuradhapura & North Central \\
Tissa WTP & \\
Nuwara tank & \\
Nuwara WTP & \\
Parakrama Samudraya & \\
\hline
\end{tabular}

Figure 1: Sampling locations of the study (WTP - water treatment plant) 
were collected directly into $20 \mathrm{~mL}$ headspace SPME vials. The vials were sealed with a twist cap (Saito et al., 2008). Samples were placed in an ice box $\left(4{ }^{\circ} \mathrm{C}\right)$, transported to the laboratory and stored in the dark at $4{ }^{\circ} \mathrm{C}$ until analysis. Sampling was performed from June 2016 to June 2017 from the raw water bodies where T\&O problems were prevailing in Sri Lanka. Twenty two raw and treated water samples were obtained covering the North Central province (Anuradhapura and Polonnaruwa districts) and Eastern province (Ampara, Trincomalee, Batticaloa districts) (Figure 1). Analysis was performed within 7 days. The water samples were saturated with molecular grade solid sodium chloride and subjected to HS-SPME/GC-MS analysis.

\section{Gas chromatography-mass spectrometry (GC/MS)}

GC-MS analysis was carried out with Agilent Model 7890A gas chromatograph-mass spectrometer. A fusedsilica capillary column with cross-linked $5 \%$ phenyl methyl siloxane of HP-5MS $(30 \mathrm{~m} \times 250 \mu \mathrm{m} \times 0.25 \mu \mathrm{m}$ film thickness) was used. The GC operating conditions were as follows: injection and detector temperatures, $270{ }^{\circ} \mathrm{C}$; inlet helium carrier gas flow rate, $1.1 \mathrm{~mL} / \mathrm{min}$ maintained by an electronic pressure controller. Injection port was operated in pulsed splitless mode and was fitted with $0.7 \mathrm{~mm}$ id SPME injection liner. Head pressure was set to $9.35 \mathrm{psi}$ of helium for $1.30 \mathrm{~min}$, then changed to a constant flow of $1.1 \mathrm{~mL} / \mathrm{min}$ to give a velocity of $38.41 \mathrm{~cm} / \mathrm{s}$. Oven was initially held at $60{ }^{\circ} \mathrm{C}$ for $1 \mathrm{~min}$, then increased by $10{ }^{\circ} \mathrm{C} / \mathrm{min}$ to $300{ }^{\circ} \mathrm{C}$ and held for $4 \mathrm{~min}$. The electron impact (EI-MS) conditions were as follows: MS source temperature, $230^{\circ} \mathrm{C}$, MS quadropole temperature, $150{ }^{\circ} \mathrm{C}$; ionising voltage, $70 \mathrm{eV}$. The full scan mass spectra were obtained at an $\mathrm{m} / \mathrm{z}$ range of $33-$ $550 \mathrm{D}$. Selected ion monitoring (SIM) mode detections for geosmin were selected at $\mathrm{m} / \mathrm{z}=112(\mathrm{GSM})$ and $\mathrm{m} / \mathrm{z}$ $=125$. These were monitored alternatively at dwell times of 1001.ts each. Optimised conditions of GC-MS are: geosmin retention time $11.15 \mathrm{~min}$, precursor ion 112 , product ion 97, dwell $20 \mathrm{~s}$ and collision energy 10 . The correlation area was measured to construct a calibration curve and to determine the concentration of geosmin in samples.

\section{Headspace solid-phase micro extraction (HS-SPME)}

A $10 \mathrm{~mL}$ volume of sample was transferred to a $20 \mathrm{~mL}$ headspace vial along with $3.0 \mathrm{~g}$ of molecular grade sodium chloride. The vial was sealed with a twist cap prior to placement on the vortex machine $(1000 \mathrm{rpm})$ for $1 \mathrm{~min}$ for agitation. The SPME needle pierced the septum of sample vial and the fiber was exposed in the headspace above the sample for $15 \mathrm{~min}$ at $40{ }^{\circ} \mathrm{C}$.
After extraction, the fiber was retracted into the needle; the needle was removed from the septum and then inserted directly into the GC-injection port of the GCMS instrument. Immediately after exposition of fiber, GC-MS temperature programming was started and the fiber was held in the GC-injection port for $5 \mathrm{~min}$. Then, the fiber was retracted into the needle. The needle was removed from the GC-injection port and used for the HSSPME of the next sample after 5 min.

\section{Optimisation of headspace solid-phase micro extraction (SPME)}

In order to optimise the extraction of geosmin by HSSPME, several extraction conditions including the sample volume, extraction time, temperature and agitation time were studied. The best sample size was found to be $10 \mathrm{~mL}$, and optimum extraction time was $15 \mathrm{~min}$ while the best extraction temperature was $40^{\circ} \mathrm{C}$. Agitation rate became constant by stirring at more than $1000 \mathrm{rpm}$, but faster agitation tends to be uncontrollable and might cause a poor measurement precision. Therefore, the stirring rate was maintained at $1000 \mathrm{rpm}$ (Saito et al., 2008). Use of $3.0 \mathrm{~g}$ of sodium chloride $(\mathrm{NaCl})$ was found to be the best salting-out agent. Various SPME fiber types have been tested for geosmin extraction efficiency from water. Medium polar SPME fiber (divinylbenzene/ carboxen/ polydimethylsiloxane) (DVB/ CAR/ PDMS) microfiber with film thickness $50 / 30 \mu \mathrm{m}$ proved to be the most efficient for geosmin extraction as geosmin is a semi volatile odorous compound. Extraction yield also increased by 1.2 times by a salting-out effect (Saito et al., 2008). Geosmin extracted on the fiber was completely desorbed within $5 \mathrm{~min}$ by heating in the GC-injection port at $270{ }^{\circ} \mathrm{C}$ and carry over was not observed because the fiber was washed during exposition. The geosmin peak was not detected by re-exposition of the fiber after heating (Saito et al., 2008). The absolute amount of geosmin extracted by HS-SPME method was calculated by comparing the correlation area of the peak.

\section{Application of optimised method for the detection of geosmin in raw and treated water samples}

The optimised method was applied to several raw and treated water samples collected from source water and water treatment plants. Geosmin peak in the water samples was identified by mass spectrum analysis.

\section{Identification and enumeration of phytoplankton}

Phytoplankton samples were collected by filtering $100 \mathrm{~L}$ of water through $55 \mu \mathrm{m}$ plankton net for identification purposes. For enumeration of algae and cyanobacteria, 
$100 \mathrm{~mL}$ of water was fixed with acidified Lugols' solution to a final concentration of $1 \%$ followed by natural sedimentation. Identification of cyanobacteria and other algae was carried out under light microscopy using standard keys (Prescott, 1978, Manage, 2013). Enumeration was done using a Sedgewick rafter counting chamber under the light microscope $(\times 40)$ in order to get species composition and abundance of cyanobacteria and algae in water samples.

\section{Measurement of water quality parameters}

During sampling, $\mathrm{pH}$, temperature, dissolved oxygen (DO) and electric conductivity of water were measured at the site using standard digital meters [ $\mathrm{pH}$ meter $(330$ I/ Set, WTW Co., Weilheim, Germany), thermometer, oxygen meter (Oxi 320/ Set, WTW Co., Weilheim, Germany) and conductivity meter (340A-Set 1. WTWCo., Weilheim, Germany, respectively]. Nitrate-N, nitrite-N, ammonia-N, total phosphorous (TP) and hardness were measured in the laboratory using standard titrimetric and spectrometric methods (APHA, 1999).

Evaluation of the preference of treated water for drinking

The NWSDB-treated water samples having T\&O problems were collected from the Tissa tank, Nuwara tank and Thuruwila tank WTPs and given to a selected group of people aged 20-60 who do not consume geosmin contaminated water in daily life. A questionnaire was prepared to evaluate the preference of water for drinking purposes. A total of 100 students, age ranging 20-24 years, both male and female and 100 adults, age ranging 25-70 years, both male and female were randomly recruited to the survey.

\section{Statistical analysis}

Principal component analysis (PCA) test and Pearson's correlation test were carried out using MINITAB 17 software.

\section{RESULTS AND DISCUSSION}

\section{Detection of geosmin and quantification}

Geosmin $200 \mu \mathrm{gL}^{-1}$ extracted by HS-SPME method was used to detect and identify geosmin via scan mode in GC/MS as per Figure 2, which demonstrates the total ion chromatogram (TIC). Geosmin peak appeared at a retention time of $11.15 \mathrm{~min}$ and mass spectra of geosmin peak was matched with NIST library spectra. Since human sensory threshold is very low as $\mathrm{nL}^{-1}$ level SIM mode was occupied for further detection. The selected

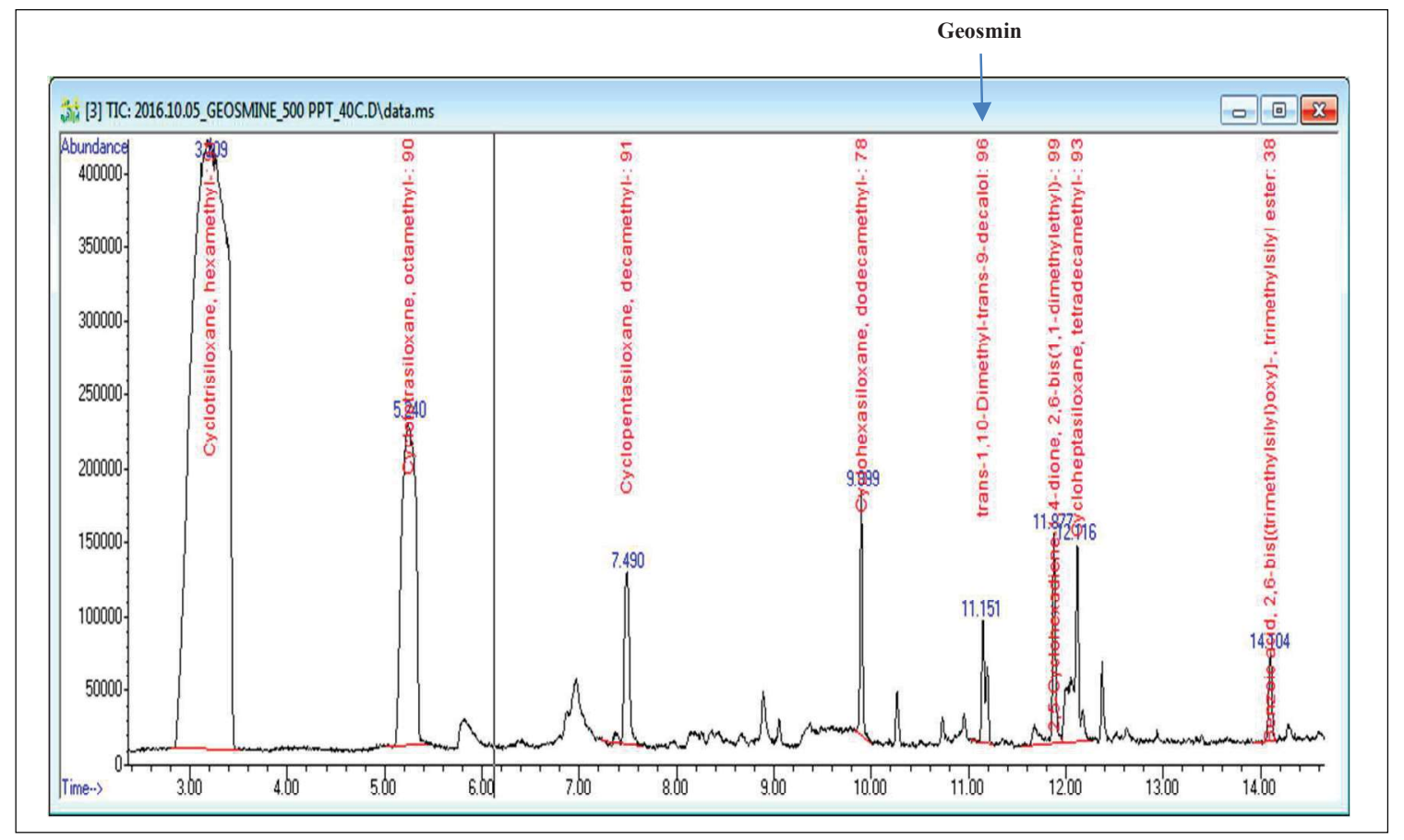

Figure 2: Total ion chromatogram of a water sample

Geosmin (trans-1, 10-dimethyl-trans-9-decalol) retention time is at $11.15 \mathrm{~min}$ 


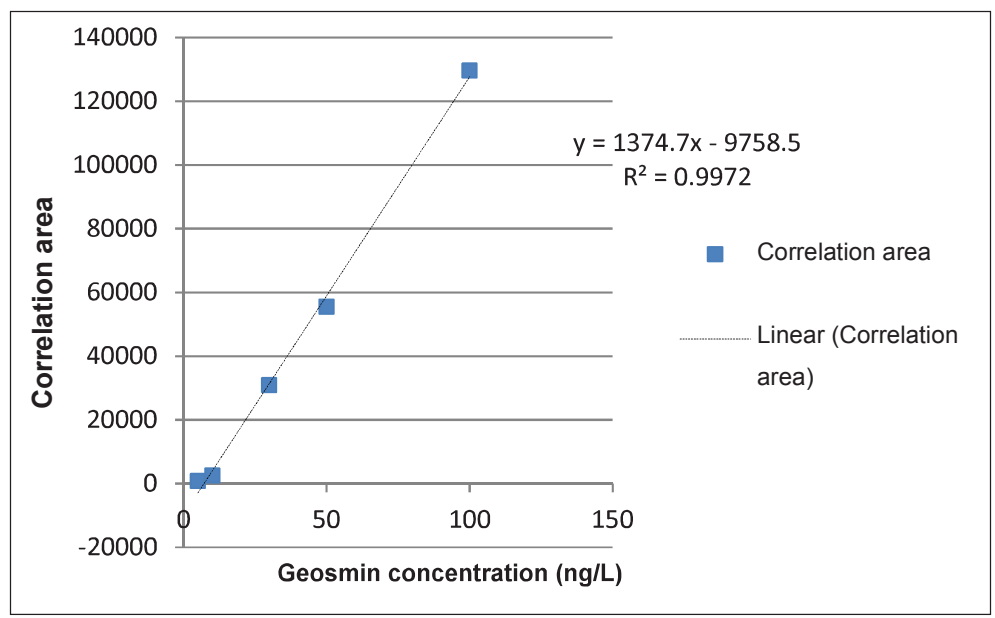

Figure 3: Calibration curve for geosmin quantification

Table 1: Geosmin levels (ng/L) in raw water and treated water collected at various water resources

\begin{tabular}{|c|c|c|c|c|c|}
\hline Water source & $\begin{array}{c}\text { Raw water } \\
\text { geosmin }(n g / L)\end{array}$ & $\begin{array}{c}\text { Treated water } \\
\text { geosmin }(n g / L)\end{array}$ & Type of treatment & District & Province \\
\hline Jayanthi tank & ND & ND & $\begin{array}{l}\text { Sand filter system and alum are used at coagulation } \\
\text { step }\end{array}$ & & \\
\hline Sagama tank & ND & 8.1 & $\begin{array}{l}\text { Membrane filter system and alum and poly } \\
\text { aluminium chloride are used at coagulation step }\end{array}$ & Amrar & \\
\hline $\begin{array}{l}\text { Kondawatuwana } \\
\text { tank }\end{array}$ & ND & ND & $\begin{array}{l}\text { Dissolved air floatation system with sand filter } \\
\text { system used. Alum, poly aluminium chloride and } \\
\text { powdered activated carbon are used at coagulation } \\
\text { step }\end{array}$ & Ampara & Eastern \\
\hline Unnichchai tank & ND & ND & $\begin{array}{l}\text { Dissolved air floatation system with sand filter } \\
\text { system used. Alum, poly aluminium chloride and } \\
\text { powdered activated carbon are used at coagulation } \\
\text { step }\end{array}$ & Batticaloa & \\
\hline Kantale tank & ND & ND & $\begin{array}{l}\text { Sand filter system and alum are used at coagulation } \\
\text { step }\end{array}$ & Trincomalee & \\
\hline $\begin{array}{l}\text { Nachchadoowa } \\
\text { tank }\end{array}$ & 8.7 & $\mathrm{NC}$ & - & Anuradhapura & $\begin{array}{l}\text { North } \\
\text { Central }\end{array}$ \\
\hline Kala tank & 8.2 & 10.3 & $\begin{array}{l}\text { Sand filter system and alum are used at coagulation } \\
\text { step }\end{array}$ & & \\
\hline Nallachchiya tank & 7.8 & $\mathrm{NC}$ & - & & \\
\hline Thuruwila tank & 8.1 & 8.5 & $\begin{array}{l}\text { Sand filter system and poly aluminium chloride are } \\
\text { used at coagulation step }\end{array}$ & & \\
\hline Tissa tank & 8.8 & 11.1 & $\begin{array}{l}\text { Sand filter system and alum are used at coagulation } \\
\text { step }\end{array}$ & & \\
\hline Nuwara tank & 10.9 & 11.2 & $\begin{array}{l}\text { Sand filter system and alum are used at coagulation } \\
\text { step }\end{array}$ & & \\
\hline $\begin{array}{l}\text { Parakrama } \\
\text { Samudra }\end{array}$ & 8.1 & $\mathrm{NC}$ & - & Polonnaruwa & \\
\hline
\end{tabular}

ND - Not detected; NC - water was not collected from the treatment plant 
ions for quantification of geosmin are of $\mathrm{m} / \mathrm{z} 112$ and 125. Geosmin eluted as a single and symmetrical peak at $11.15 \mathrm{~min}$. It gave excellent response to GCMS-SIM detection and the minimum detectable level (MDL) of geosmin by HS-SPME/GC-MS under

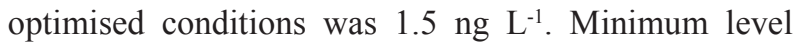
of quantification (MQL) was $3.5 \mathrm{ng} \mathrm{L}^{-1}$. Both values are below the minimum threshold levels where human olfactory system detects geosmin at $5 \mathrm{ng} \mathrm{L}^{-1}$. As shown in Figure 3, an excellent linear correlation of peak area and level of geosmin was obtained $\left(\mathrm{R}^{2}=0.998\right)$ for

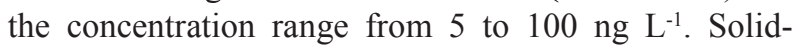
phase micro extraction integrates sampling, extraction, concentration and sample introduction into a single solvent-free step and analytes in the sample are directly extracted and concentrated to the extraction fiber. The optimised method is cost effective and saves sample preparation time.

Application of optimised method for the detection of geosmin in raw and treated water samples

Table 1 shows geosmin levels in raw and treated water samples collected at various water resources. The sampling was done in October (dry season) in the North Central province and in February (wet season) in the Eastern province. The levels of geosmin in raw water bodies ranged from 7.8 to $10.9 \mathrm{ng} \mathrm{L}^{-1}$ whereas in treated water it ranged from 8.1 to $11.2 \mathrm{ng} \mathrm{L}^{-1}$.

Among the selected raw water bodies, the highest level of geosmin was recorded in Nuwara tank (10.9 $\left.\mathrm{ng} \mathrm{L}^{-1}\right)$ while the lowest was detected in Nallachchiya tank (7.8 $\mathrm{ng} \mathrm{L}^{-1}$ ). Detectable levels of geosmin was not present in Sagama tank, Kantale tank, Kondawatuwana tank, Jayanthi tank and Unnichchai tank during sampling. This may be due to the samples being collected during the rainy season in these raw water bodies causing dilution of the available geosmin level. Further, according to literature, geosmin is released more at warm stratified season of the dry period compared to the rainy period (Bertone \& O'Halloran, 2016). Therefore, geosmin levels not being detected during the wet season in the above water bodies can be explained. Further, treated water from Nuwara tank WTP recorded the highest geosmin concentration $\left(11.2 \mathrm{ngL}^{-1}\right)$ while treated water from Sagama tank WTP recorded the lowest $\left(8.1 \mathrm{ngL}^{-1}\right)$. Treatment plants of Kondawatuwana tank, Jayanthi tank, Unnichchai tank and Kantale tank did not record geosmin at detectable levels during the wet season. Not detecting geosmin in treated water may be due to the lack of presence of geosmin in respective raw water bodies used for treatment processes. Water treatment plants at
Kondawatuwana and Unnichchai tanks have activated carbon beds, which are capable of removing geosmin (Drikas et al., 2009; Kim et al., 2014). Kanthale WTP uses both reservoir water and Mahaweli river water as a mixture for treatment processes. It has been recorded that cyanobacteria cell growth in rivers is significantly lower than in reservoirs (Okogwu \& Ugwumba, 2009). This could be another reason for not detecting geosmin in treated water from Kanthale tank. Although there is no recommended standard level for $\mathrm{T} \& \mathrm{O}$ in drinking water by WHO or by the Sri Lanka Standards Institute (SLSI), it is clearly mentioned that T\&O should be at 'unobjectionable' levels, which again means below the human threshold levels or $5 \mathrm{ngL}^{-1}$ (BOI, 1999). The present results revealed that in $68 \%$ of the sampling locations covering 5 districts (Anuradhapura, Polonnaruwa, Ampara, Batticaloa and Trincomalee), the human threshold level for geosmin was exceeded. Moreover, geosmin levels in treated water from WTPs were higher than the geosmin levels in the respective raw water bodies and some water purification steps may have caused that elevated level of geosmin, which again lead to consumer rejection of treated water. Moreover, at Sagama tank WTP, treated water recorded a geosmin level of $8.1 \mathrm{ngL}^{-1}$ when reservoir water did not detect geosmin. At Sagama tank WTP, there are no activated carbon beds although they use powdered activated carbon occasionally when T\&O episodes occur. The treatment facility in Sagama tank is a membrane filter system with alum and poly aluminium chloride at coagulation step. These facilities do not seem to be very effective in removing geosmin when compared to activated carbon (Drikas et al., 2009; Kim et al., 2014). Geosmin is a secondary metabolite of a range of cyanobacteria and algae in raw water, and it is present both in solution and suspended form mostly associated with the host cyanobacteria (Ashitani et al., 1988). According to Ashitani et al. (1988), geosmin in suspended form were removed well by coagulation and sedimentation alone. Geosmin present in solution can be removed almost to an undetectable level in the rapid sand filter where no pre-chlorination is practiced. However, when raw water enters specific processing steps of the WTPs such as pre-chlorination, cyanobacteria cells disintegrate and cell lysis occurs (Ashitani et al., 1988). At that point, geosmin leaks out to the water and leads to an elevated level of geosmin in treated water than the geosmin level in the respective raw water. During sampling, a noted feature was the different water treatment methods used in various water treatment steps such as dissolved air floatation systems, membrane filtration systems and activated carbon beds. Most of the plants had conventional water treatment methods (aeration, pre-sedimentation, filtration, sedimentation, 
Table 2: Species composition of algae and cyanobacteria vs geosmin concentration in water bodies

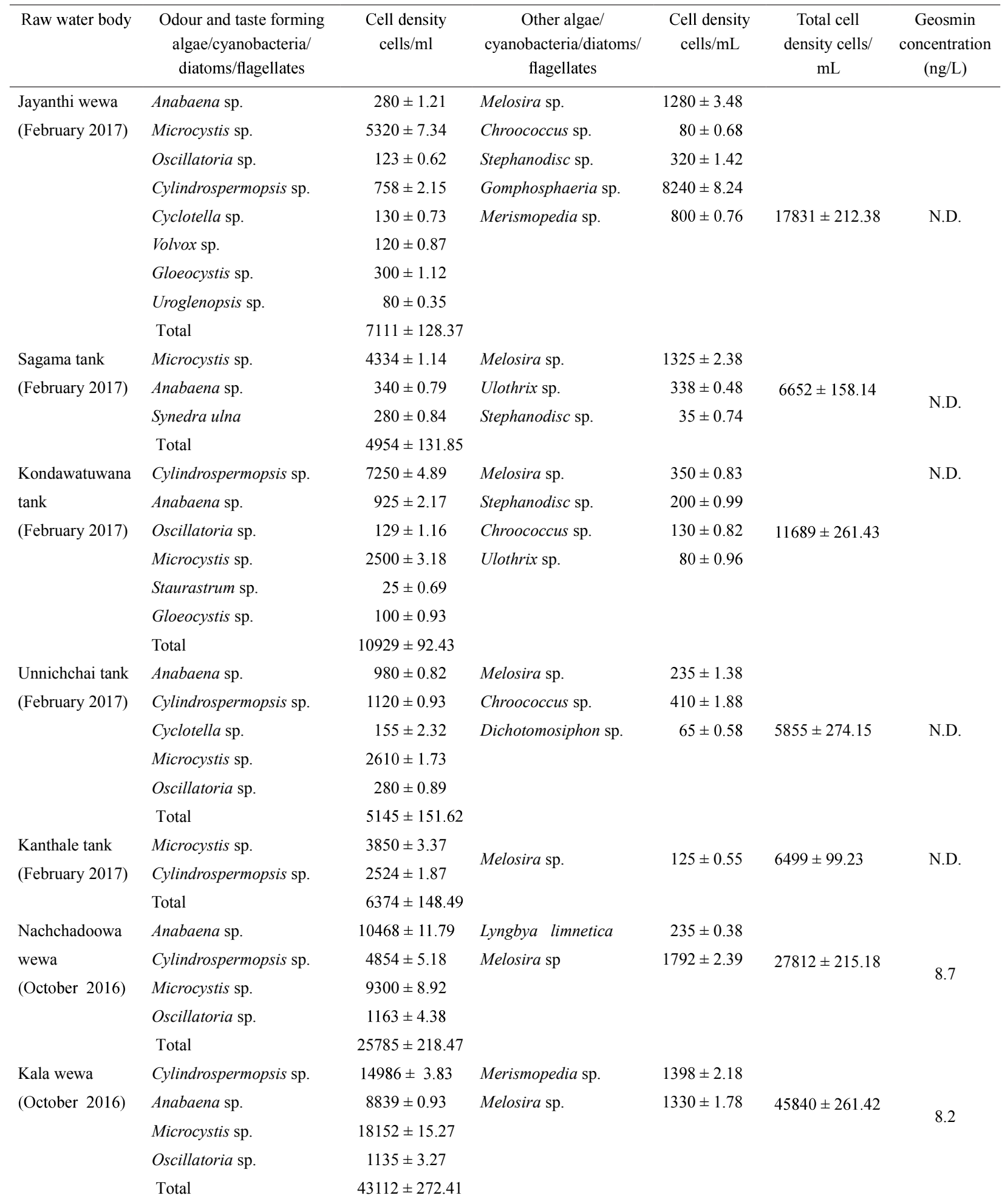

continued - 
- continued from page 252

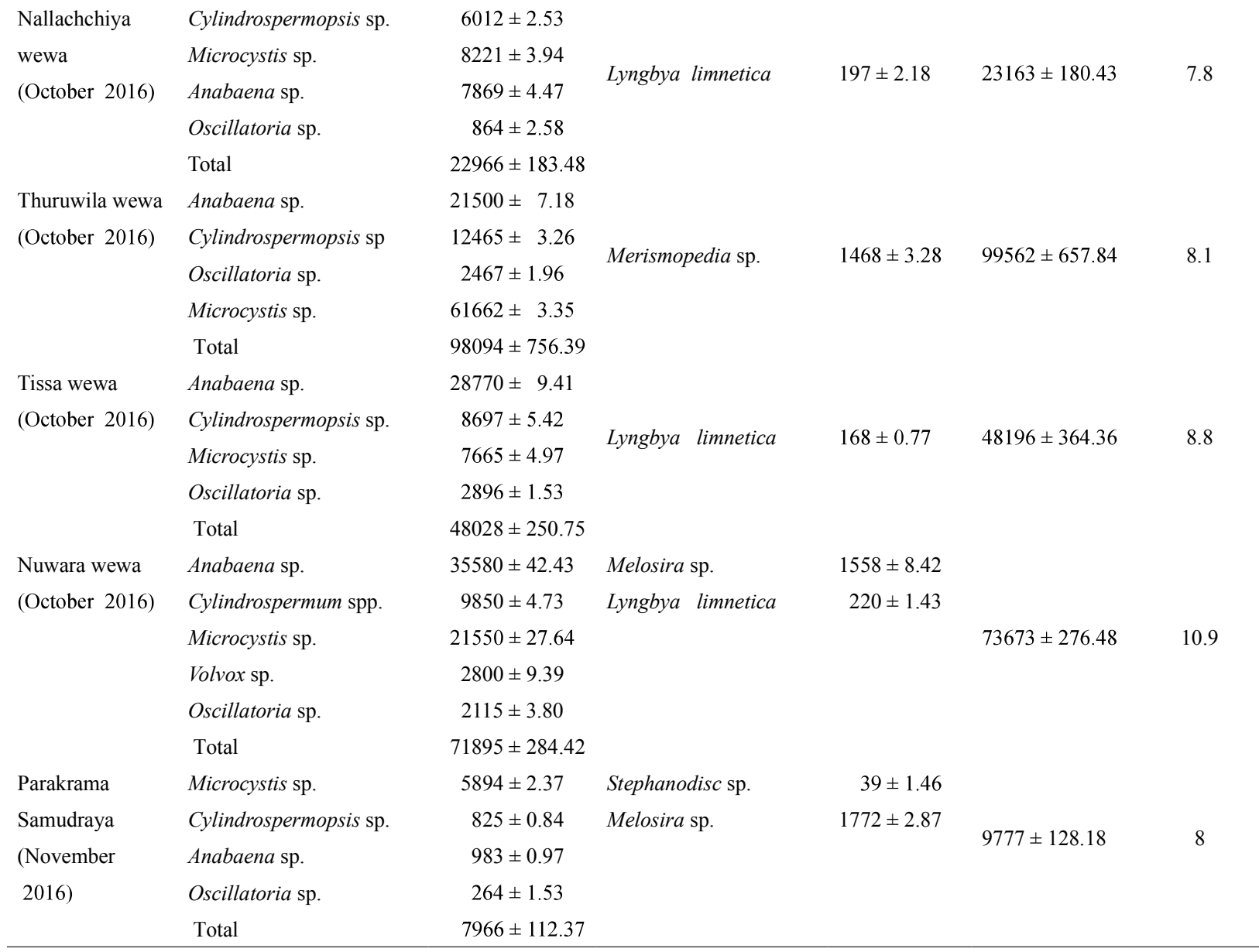

flocculation, coagulation, disinfection) where some plants used modern technological methods such as dissolved air floatation systems (DAF) (Kondawatuwana WTP, Unnichchai (Wawnativ) WTP), membrane filtration systems (Sagama WTP) and activated carbon beds (Kondawatuwana WTP, Unnichchai WTP). Generally, when sand filtration is applied as a step in the treatment of raw water, there is an increase in geosmin content after treatment. The highest increase in geosmin content (Table 1) after treatment was from the Tissa tank in Anuradhapura. According to NWSDB (unpublished data), back in 1987, a $5 \mathrm{~cm}$ thick black layer was found just underneath the sand filtration layer of the Tissa WTP. This layer had loads of actinomycetes, which could aggravate the geosmin content during filtration (Klausen et al., 2005). Moreover, previous studies have concluded that geosmin is produced by actinomycetes (Gerber \&
Lechevalier, 1965; Klausen et al., 2004; Klausen et al., 2005; Jüttner \& Watson, 2007; Lee et al., 2011; Park et al., 2014). The special water treatment facilities in each plant except for the conventional processes are stated in Table 1. Powder activated carbon (PAC) and granular activated carbon (GAC) are one of the key compounds used over the world to solve the issue T\&O in water (Drikas et al., 2009; Kim et al., 2014). It was noted that geosmin levels were not detected in treated water, which had PAC or GAC beds in the treatment plants (Kondawatuwana and Unnichchi) (Table 2). It was observed during field visits that GAC or PAC safe doses added into the water has been found to be a good solution when T\&O problem appears in water occasionally even with the treatment plants where PAC or GAC beds are unavailable (Kim et al., 2014, Drikas et al., 2009). 


\section{Identification and enumeration of phytoplankton}

Species composition and the number of algae/ cyanobacteria/ diatoms and flagellates in each raw water body, geosmin concentration vs T\&O forming species composition and number are stated in Table 2. Some T\&O producing cyanobacteria and algae species such as Anabaena sp., Cylindrospermum spp., Microcystis sp., and Oscillatoria sp. were identified and quantified in the selected raw water bodies during the study.

T\&O producing algae and cyanobacteria cell density ranged between 4954 to 98094 cells $\mathrm{mL}^{-1}$ and Sagama tank had the lowest and Thuruwila tank had the highest cell density during February 2017 and October 2016, respectively. Considering the geosmin concentration, in Sagama tank where the lowest cell density was recorded, geosmin was not detected; in Thuruwila tank where the highest cell density was recorded, a high level of geosmin was detected. Nuwara wewa, where the highest geosmin level was detected (10.9 ng/L) also recorded high algae and cyanobacteria cell density $\left(71895 \pm 284\right.$ cells $\left.\mathrm{mL}^{-1}\right)$. A strong positive correlation between total T\&O forming algae and cyanobacteria cell count and geosmin levels was detected and the results were statistically significant with a Pearson correlation coefficient of 0.691 according to Cohen et al. (1998) ( $\mathrm{p}<0.05)$. The present study shows that when the number of T\&O forming cyanobacteria and algae are higher, geosmin level also increased significantly $(\mathrm{p}<0.05)$. During the sampling

Table 3: Physico chemical parameters of collected water

\begin{tabular}{|c|c|c|c|c|c|c|c|c|c|c|}
\hline Raw water body & $\begin{array}{l}\text { Time of } \\
\text { collection }\end{array}$ & $\begin{array}{c}\text { Tem. } \\
{ }^{\circ} \mathrm{C}\end{array}$ & $\mathrm{pH}$ & $\begin{array}{c}\mathrm{DO} / \\
\mathrm{mg} / \mathrm{L}\end{array}$ & $\begin{array}{l}\text { Cond./ } \\
\mu \mathrm{scm}^{-1}\end{array}$ & $\begin{array}{l}\text { Nitrate- } \\
\text { Nmg/L }\end{array}$ & $\begin{array}{l}\text { Nitrite- } \\
\text { Nmg/L }\end{array}$ & $\begin{array}{c}\text { Ammonia- } \\
\mathrm{Nmg} / \mathrm{L}\end{array}$ & $\begin{array}{c}\text { Total } \\
\text { Phosphorous } \\
\text { (TP) } \mathrm{mg} / \mathrm{L}\end{array}$ & $\begin{array}{c}\text { Total } \\
\text { Hardness } \\
\text { mg/L }\end{array}$ \\
\hline $\begin{array}{l}\text { Recommended } \\
\text { level for drinking }\end{array}$ & & & $6.5-8.5$ & & 3500 & 50 & 3 & 0.06 & 2 & 250 \\
\hline $\begin{array}{l}\text { Jayanthi wewa } \\
\text { (February 2017) }\end{array}$ & $7.53 \mathrm{AM}$ & 25.3 & 7.14 & 6.78 & 147.2 & 0.07 & $<0.01$ & $<0.01$ & $<0.01$ & 56.0 \\
\hline $\begin{array}{l}\text { Sagama tank } \\
\text { (February 2017) }\end{array}$ & $10.51 \mathrm{AM}$ & 29.0 & 7.57 & 7.42 & 129.1 & $<0.01$ & $<0.01$ & $<0.01$ & $<0.01$ & 56.0 \\
\hline $\begin{array}{l}\text { Kondawatuwana } \\
\text { tank } \\
\text { (February 2017) }\end{array}$ & $1.00 \mathrm{PM}$ & 32.0 & 8.00 & 8.97 & 154.4 & 0.24 & $<0.01$ & $<0.01$ & $<0.01$ & 64.0 \\
\hline $\begin{array}{l}\text { Unnichchai tank } \\
\text { (February 2017) }\end{array}$ & $5.00 \mathrm{PM}$ & 30.1 & 8.21 & 8.56 & 168.1 & 0.31 & $<0.01$ & $<0.01$ & $<0.01$ & 60.0 \\
\hline $\begin{array}{l}\text { Kanthale tank } \\
\text { (February 2017) }\end{array}$ & $9.00 \mathrm{AM}$ & 28.5 & 7.33 & 7.81 & 182.8 & 0.577 & $<0.01$ & $<0.01$ & $<0.01$ & 120.0 \\
\hline $\begin{array}{l}\text { Nachchadoowa } \\
\text { tank } \\
\text { (October 2016) }\end{array}$ & $10.00 \mathrm{AM}$ & 28.5 & 8.27 & 7.85 & 719.0 & 0.27 & 0.47 & $<0.01$ & $0.28 \pm 2.4$ & $128.0 \pm 0.01$ \\
\hline $\begin{array}{l}\text { Kala tank } \\
\text { (October 2016) }\end{array}$ & $11.37 \mathrm{AM}$ & 29.1 & 8.11 & 7.24 & 279.1 & $0.29 \pm 0.01$ & 0.45 & $<0.01$ & $0.26 \pm 0.09$ & $36.0 \pm 0.05$ \\
\hline $\begin{array}{l}\text { Nallachchiya tank } \\
\text { (October 2016) }\end{array}$ & $2.22 \mathrm{PM}$ & 30.2 & 8.23 & 8.07 & 172.3 & 0.45 & 0.52 & $<0.01$ & 0.14 & $72.0 \pm 0.02$ \\
\hline $\begin{array}{l}\text { Thuruwila tank } \\
\text { (October 2016) }\end{array}$ & 4.12 PM & 28.2 & 8.41 & 8.50 & 478 & 0.58 & $0.55 \pm 0.01$ & $<0.01$ & $0.29 \pm 0.08$ & $144.0 \pm 0.03$ \\
\hline $\begin{array}{l}\text { Tissa tank } \\
\text { (October 2016) }\end{array}$ & 5.02 PM & 29.1 & 8.62 & 8.06 & 440 & 0.24 & 16.54 & $<0.01$ & 0.18 & $112.0 \pm 0.12$ \\
\hline $\begin{array}{l}\text { Nuwara tank } \\
\text { (October 2016) }\end{array}$ & 5.58PM & 28.4 & 8.51 & 7.85 & 462 & 0.24 & 1.85 & 0.01 & 0.13 & $112.0 \pm 0.01$ \\
\hline $\begin{array}{l}\text { Parakrama } \\
\text { Samudraya } \\
\text { (November 2016) }\end{array}$ & $3.00 \mathrm{PM}$ & 30.5 & 8.48 & 7.38 & 320.5 & 0.03 & $0.02 \pm 1.76$ & $<0.01$ & $0.16 \pm 0.04$ & 70.0 .0 \\
\hline
\end{tabular}


period Anabaena sp. was recorded as the dominant species in Tissa tank $\left(28770 \pm 9.41\right.$ cells $\left.\mathrm{mL}^{-1}\right)$, Nuwara tank (35580 \pm 42.43 cells $\left.\mathrm{mL}^{-1}\right)$, and Nachchadoowa tank $\left(10468 \pm 12\right.$ cells $\left.\mathrm{mL}^{-1}\right)$. Cylindrospermum spp. $\left(7250 \pm 5\right.$ cells $\left.\mathrm{mL}^{-1}\right)$, was recorded as the dominant species in Kondawatuwana tank. Microcystis sp. was dominant in majority of the tanks such as Parakrama Samudra, Thuruwila tank, Nallachchiya tank, Kala tank, Kantale tank, Unnichchai tank, Sagama tank and Jayanthi tank. Further, Oscillatoria sp., Anabaena sp. and Cylindrospermopsis sp. had significant positive correlations $(p<0.05)$ with the geosmin level with Pearson correlation coefficients of $0.765,0.750$ and 0.620 , respectively. However, any significant correlation was not observed between Microcystis sp. cell density and geosmin level. According to Shang et al. (2018) the concentration of geosmin had no relationship with Microcystis sp. count. Chen et al. (2010) also supports this evidence with their study. Interestingly, highest levels of geosmin was recorded in the tanks where Anabaena sp. was dominant such as Nuwara tank (10.9 $\left.\mathrm{ngL}^{-1}\right)$, Tissa tank, (8.8 $\left.\mathrm{ngL}^{-1}\right)$ and Nachchadoowa tank, $\left(8.7 \mathrm{ngL}^{-1}\right)$. Anabaena sp. cell densities in these tanks were recorded as 35580,28770 and 10468 cells $\mathrm{mL}^{-1}$, accordingly. This clearly shows that geosmin level and Anabaena sp. cell density has a strong correlation. This result resembles Oh et al. (2017) where Anabaena sp. was found to be a high geosmin producing genus. Moreover, the reason for Thuruwila tank to not record the highest level of geosmin despite it having the highest level of T\&O forming cell density can also be explained using this correlation. In Thuruwila tank, Microcystis sp. is the dominant species and Anabaena sp. is the co-dominant species. It was observed that at Parakrama Samudra, the total T\&O forming cyanobacteria cell density was lower compared to other raw water bodies (7966 \pm 112.37 cells $\mathrm{mL}^{-1}$ ), but the recorded geosmin level was comparatively high as $8 \mathrm{ng} / \mathrm{L}$. This result was observed during the rainy season and the dominant species was Microcystis sp. during that time period as well. Although algal blooms, and thus T\&O events typically occurred in warm stratified seasons, some studies have shown that high geosmin levels can be detected during lake circulation periods and how low, instead of high, temperatures can stimulate the production of geosmin (Bertone \& Halloran, 2016). Moreover, the sources of geosmin are not only cyanobacteria but could be due to the presence of geosmin producing actinomycetes, other vegetation and some standing timber. Therefore, these sources might have caused the high geosmin level in Parakrama Samudra at that time period despite the low cyanobacteria availability.

\section{Measurement of water quality parameters}

Raw water was analysed for various physico-chemical parameters as given in Table 3. According to the results, all the raw water bodies tested had safe $\mathrm{pH}$, conductivity, hardness, total phosphorous (TP), N-nitrate and $\mathrm{N}$-ammonia for drinking purposes according to SLSI drinking water standards. Tissa tank had a higher $\mathrm{N}$-nirite level, which exceeds the safe range for drinking according to SLSI drinking water standards. All other raw water bodies had a safe N-nirite level for drinking.

Phosphorous availability is generally believed to be the limiting nutrient determining the rate of production of cyanobacteria and is likely the limiting factor for algal growth in most freshwater systems (Saadoun et al., 2001; Ji et al., 2017). A significant positive correlation between total phosphrous and geosmin level with a Pearson correlation coefficient of 0.850 ( $p<0.05$ ) was found indicating that total phosphorous may be the limiting factor for algae and cyanobacteria growth which enhances the production of geosmin (Saadoun et al., 2001; Christinesen et al., 2003). This evidence corresponds with $\mathrm{Oh}$ et al. (2017), which concluded that the growth of Anabaena sp., one of the main geosmin producing genera, is dependent on phosphorous concentration. Moreover, there was a significant positive correlation between electrical conductivity and geosmin level with a Pearson correlation coefficient of 0.796 $(p<0.05)$. A significant strong correlation was found between $\mathrm{pH}$ and geosmin level with a Pearson correlation coefficient of $0.788(\mathrm{p}<0.05)$. This indicates that a high concentration of dissolved ions, high alkalinity and algae and cyanobacteria support the production of geosmin in water. According to Ji et al. (2017), alkalinity is a known optimum condition for cyanobacteria and a high cyanobacteria concentration will produce higher geosmin content (Okogwu \& Ugwumba, 2009; Ji et al., 2017). Significant positive correlations were observed between total phosphorous and total T\&O forming cell density with Pearson correlation coefficient of 0.689 ( $\mathrm{p}<$ 0.05 ), and between electrical conductivity and total T\&O forming cell density with a Pearson correlation coefficient of $0.612(p<0.05)$. This suggests total T\&O forming cells thrive more in environments where high concentrations of total phosphorous and dissolved ions are available and in return produces more geosmin (Saadoun et al., 2001; Oh et al., 2017). This provides evidence to the fact that cyanobacteria cells produce geosmin. Moreover, from statistical analyses it was found that there is a direct positive correlation among geosmin, cyanobacteria and total phosphorous with a Pearson correlation coefficient 
of $0.691(\mathrm{p}<0.05)(\mathrm{Oh}$ et al., 2017). This points to the fact that high phosphorous levels increase the growth of cyanobacteria and high cyanobacteria levels produce higher geosmin levels in water (Saadoun et al., 2001; Christinesen et al., 2003). Nutrients, particularly nitrogen and phosphorous have been identified as major reasons why much of the Nation's surface water is considered degraded with respect to water quality (USEPA, 2000). Nutrients are also important in T\&O occurrences. According to TN:TP ratio calculation (Abell et al., 2010), Jayanthi tank, Sagama tank, Nachchadoowa tank, Kala tank, Nallachchiya tank, Thuruwila tank and Parakrama Samudra were found to have a nitrogen limiting situation $(\mathrm{N}: \mathrm{P}<10)$, while Kondawatuwanana tank, Unnichchai tank, Kanthale tank and Tissa tank have a phosphorous limiting situation (N:P>17). Nuwara tank showed a N:P ratio indicating that either nitrogen or phosphorous can be limited (N: $\mathrm{P}=10-17)$. Nitrogen and phosphorous can affect the trophic conditions or the degree of biological activity. Nutrient enrichment (eutrophication) can lead to excessive growth of algae, particularly cyanobacteria, with subsequent geosmin production and T\&O problems (Davis \& Shaw, 2009). Principal component analysis was conducted for the results (Figure 4) and the principal components, $\mathrm{PC} 1$ and $\mathrm{PC} 2$ contributed about $69.7 \%$ of the total variance in the data (Table 4). PC1 as given in Table 4, has variance 4.67 and accounts for $52 \%$ of the total variance.

Table 4: Summary of eigenvalues and correlation matrix of principal component analysis

\begin{tabular}{llllllllll} 
& \multicolumn{8}{c}{ Eigen analysis of the correlation matrix } \\
Eigenvalue & 4.6783 & 1.5964 & 1.0739 & 0.7534 & 0.4129 & 0.2903 & 0.1395 & 0.0359 & 0.0193 \\
Proportion & 0.520 & 0.177 & 0.119 & 0.084 & 0.046 & 0.032 & 0.016 & 0.004 & 0.002 \\
Cumulative & 0.520 & 0.697 & 0.817 & 0.900 & 0.946 & 0.978 & 0.994 & 0.998 & 1.000
\end{tabular}

Correlation matrix of principal component analysis

$\begin{array}{lrrr}\text { Variable } & \text { PC1 } & \text { PC2 } & \text { PC3 } \\ \text { Total Cell Density } & 0.388 & -0.093 & -0.117 \\ \text { pH } & 0.365 & 0.092 & 0.438 \\ \text { DO } & 0.125 & -0.588 & 0.499 \\ \text { Conductivity } & 0.405 & 0.179 & -0.108 \\ \text { Nitrate-N } & 0.191 & -0.636 & -0.238 \\ \text { Nitrite-N } & 0.193 & 0.166 & 0.598 \\ \text { Total phosphorous } & 0.402 & 0.171 & -0.235 \\ \text { Hardness } & 0.369 & -0.248 & -0.251 \\ \text { Geosmin } & 0.407 & 0.285 & -0.038\end{array}$
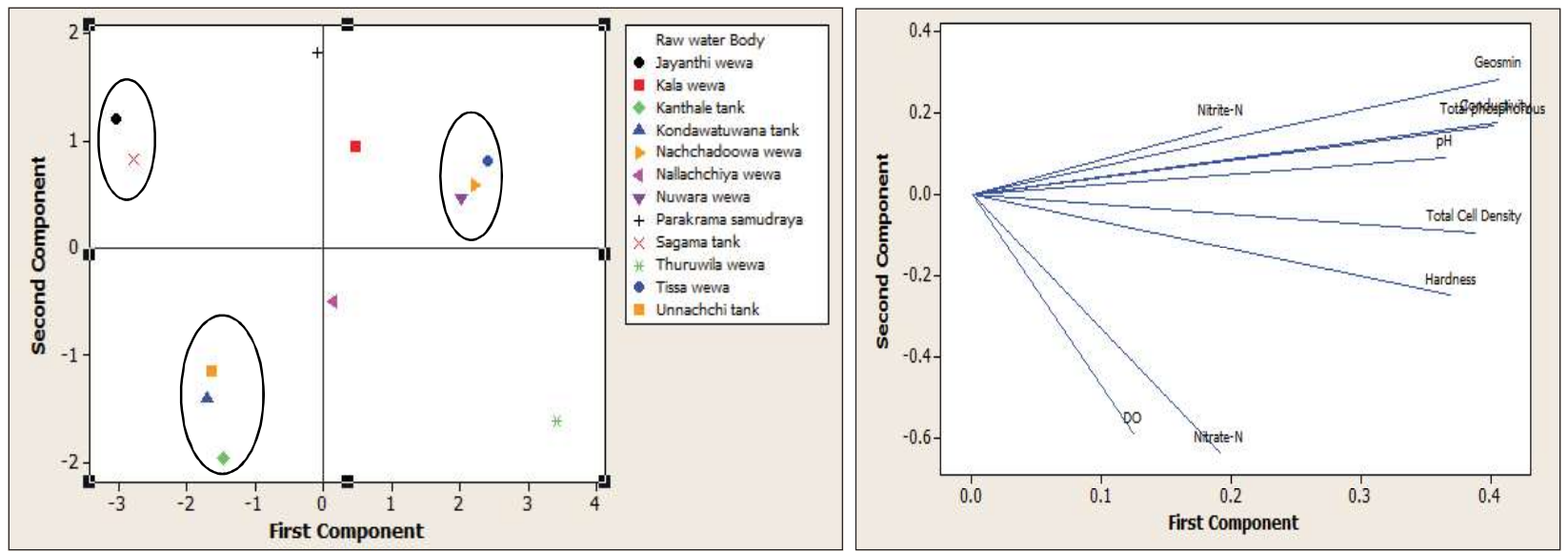

Figure 4: Principal component analysis (PCA): (a) score plot; (b) loading plot 
The coefficients listed under PC1 in Table 4 shows the calculation of principal component scores: PC1 = 0.388 total cell density $+0.365 \mathrm{pH}+0.125 \mathrm{DO}+0.405$ cond. +0.191 nitrate- $\mathrm{N}+0.193$ nitrite-N +0.402 total phosphorous +0.369 hardness +0.407 geosmin.

PC1 is contributed by geosmin, total phosphorous and conductivity, although there is no parameter value obtained above 0.5 . The second principal component has a variance of 1.59 and accounts for $17.7 \%$ of the data variability. It is calculated from the original data using the coefficients listed under PC2. PC2 is strongly contributed by nitrate- $\mathrm{N}$ and dissolved oxygen. Together, the first two and three components represent $69.7 \%$ and $81.7 \%$ of the data variability respectively, of the total variability. Thus, most of the data structure can be captured in two or three underlying dimensions. The remaining principal components account for a very small proportion of the variability and are probably unimportant. Eigen values greater than 1.0 were used for PCA scoring and three scores were selected (Table 2). $\mathrm{PC} 1$ explains $52 \%$ of total variance of the data with $52 \%$ cumulative variation and PC2 explains 17.7 $\%$ of total variance of the data with $69.7 \%$ cumulative variation. In the score plot of PC2 versus PC1, three clusters can be identified along the PC1 axis. The groups I, II and III correspond to samples with different water quality parameters. $\mathrm{pH}$, conductivity, geosmin, total phosphorous, total cell density, hardness, DO, nitrite-N and nitrate- $\mathrm{N}$ exhibited a strong relationship among them and also influence the separation of the three groups along PC1. Nuwara wewa, Tissa wewa and Nachchadoowa wewa were clustered together with high geosmin, $\mathrm{pH}$, conductivity, total phosphorous and total odour and taste forming cell density values, whereas Unnichchai tank, Kondawatuwana tank and Kanthale tank were clustered together with similar nitrate-N and DO values. The third cluster consisted of Jayanthi wewa and Sagama tank with similar nitrite- $\mathrm{N}$ values.

In the questionnaire survey, $95 \%$ of students rejected geosmin contaminated water, whereas only $5 \%$ accepted geosmin contaminated water for drinking purposes $(n=100)$. In the non-student category, $98 \%$ adults rejected and only $2 \%$ adults accepted geosmin contaminated water for drinking purposes $(n=100)$.

\section{CONCLUSION}

The present study concludes that geosmin is one of the causes for $\mathrm{T} \& \mathrm{O}$ problems in drinking water in some parts of Sri Lanka. More than $95 \%$ consumers rejected drinking water contaminated with geosmin. A total of $68 \%$ of the water sampling locations covering 5 districts exceeded the human threshold level of geosmin. Geosmin concentration in treated water from water treatment plants were higher than the geosmin concentration in relevant raw water bodies. PCA analysis pooled three different clusters of water bodies. The solvent-free HSSPME/GC-MS method developed in this study is simple and sensitive for analysis of geosmin. It can be directly applied to the analysis of a small volume of environmental water samples without any pretreatment. Therefore, this method provides a useful tool for the screening and determination of geosmin in water analysis.

\section{Acknowledgement}

The authors acknowledge the National Science Foundation for financial support (Grant number RG/2016/EB04). The Centre for Water Quality and Algae Research, Department of Zoology, Central Instrumentation Facility, Faculty of Applied Sciences, University of Sri Jayewardenepura and the National Water Supply and Drainage Board (NWSDB), are acknowledged for the instrument facilities, technical advice and other logistic support provided.

\section{REFERENCES}

Abell J.M., Özkundakci D. \& Hamilton D.P. (2010). Nitrogen and phosphorous limitation of phytoplankton growth in New Zealand lakes: implications for eutrophication control. Ecosystems 13(7): 966-977.

DOI: https://doi.org/10.1007/s10021-010-9367-9

American Public Health Association (APHA) (1999). Standard Methods for the Examination of Water and Wastewater. American Public Health Association, USA.

Ashitani K., Hishida Y. \& Fujiwara K. (1988). Behavior of musty odorous compounds during the process of water treatment. Water Science and Technology 20 (8-9): 261267.

DOI: https://doi.org/10.2166/wst.1988.0251

AWWA Research Foundation (AWWARF) (2000). Assessment of Blue-Green Algal Toxins in Raw and Finished Drinking Water. AWWA Research Foundation, USA.

Bertone E. \& O'Halloran K.A. (2016). Analysis and modelling of taste and odour events in a shallow subtropical reservoir. Environments 3(3): 22.

DOI: https://doi.org/10.3390/environments3030022

Board of Investment of Sri Lanka (BOI) (1999). Drinking Water Standards: Environmental Norms. Board of Investment, Sri Lanka.

Cayelan C., Carey A., Ibelings B.W., Hoffmann E.P., Hamilton D.P. \& Brookes J.D. (2012). Eco-physiological adaptations that favour freshwater cyanobacteria in a changing climate. Water Research Journal 46:1394-1407.

DOI: https://doi.org/10.1016/j.watres.2011.12.016

Chen J., Xie P., Ma Z., Niu Y., Tao M., Deng X. \& Wang Q. (2010). A systematic study on spatial and seasonal patterns 
of eight taste and odor compounds with relation to various biotic and abiotic parameters in Gonghu Bay of Lake Taihu, China. The Science of the Total Environment 409(2): 314-325.

DOI: https://doi.org/10.1016/j.scitotenv.2010.10.010

Christensen V.G., Graham J.L., Milligan C.R., Pope L.M. \& Ziegler A.C. (2006). Water quality and relation to tasteand odor compounds in the North Fork Ninnescah River and Cheney Reservoir, South-Central Kansas (19972003). Scientific Investigations Report 2006-5095. U.S. Department of the Interior \& U.S. Geological Survey, USA. DOI: https://doi.org/10.3133/sir20065095

Cohen L.H., Cimbolic K., Armeli S.R. \& Hettler T.R. (1998). Quantitative assessment of thriving. Journal of Social Issues 54(2): 323-335.

DOI: https://doi.org/10.1111/0022-4537.681998068

Davis J.L. \& Shaw G. (2009). Impacts of eutrophication of the safety of drinking and recreational water. Encyclopedia of Life Support Systems (EOLSS); Water and Health, volume 2. Eolss Publishers Company Ltd., Cambridge, UK.

Ding Z., Peng S., Xia W., Zheng H., Chen X. \& Yin L. (2014a). Analysis of five earthy-musty odorants in environmental water by HS-SPME/GC-MS. International Journal of Analytical Chemistry 2014: 11.

DOI: http://dx.doi.org/10.1155/2014/697260

Ding Z., Peng S., Jin Y., Xuan Z., Chen X. \& Yin L. (2014b). Geographical and seasonal patterns of geosmin and 2-methylisoborneol in environmental water in Jiangsu Province of China. Journal of Analytical Methods in Chemistry 74(3): 924-929.

DOI: https://doi.org/10.1155/2014/743924

Drikas M., Dixon M. \& Morran J. (2009). Removal of MIB and geosmin using granular activated carbon with and without MIEX pre-treatment. Water Research 43(20): 5151-5159. DOI: https://doi.org/10.1016/j.watres.2009.08.016

Gerber N. \& Lechevalier H. (1965). Geosmin, an earthysmelling substance isolated from actinomycetes. Applied Microbiology 13(6): 935-938.

Hettiarachchi I.U. \& Manage P.M. (2014). Cyanobacterial cell density and intracellular microcystin-LR levels in drinking/ irrigation reservoirs in Anuradhapura, Sri Lanka. In: Global Climate Change and Sustainability Pathways. Proceedings of ENRIC 2014 Symposium, Thailand, pp. 210-214.

Hettiarachchi I.U., Manage P.M., Sumanaweera S. \& Jayesiriwardene D.S.D. (2013). Nuisance algae and cyanobacteria in some selected water bodies in Sri Lanka, Proceedings of Water Quality and Human Health International Symposium. Postgraduate Institute of Science, University of Peradeniya, Sri Lanka, p. 33.

Ho L., Plant T., Kayal P., Slyman N. \& Newcombe P. (2009). Optimising water treatment practices for the removal of Anabaena circinalis and its associated metabolites, geosmin and saxitoxins. Journal of Water Health 7(4): 544-556.

DOI: https://doi.org/10.2166/wh.2009.075

Idroos S.F. (2015). Isolation, identification and characterization of microcystin degrading bacteria for water treatement solution. PhD thesis, University of Sri Jayawardenapura, Sri Lanka.
Idroos S.F., Manage P.M., De Silva B.G.D.N.K. \& Karunanayaka L. (2015). Development of a laboratory scale sand filter with microcystin-LR degrading Bacillus cereus. Proceedings of the Academic World $12^{\text {th }}$ International Conference, Singapore, 20 December, pp. 06-09.

Izaguirre G. \& Taylor W.D. (2007). Geosmin and MIB events in a new reservoir in southern California. Technology 55(5): 9-14.

DOI: https://doi.org/10.2166/wst.2007.156

Jade G. \& Emilia E. (2013). Reduction of off-flavor compounds (gas-main and 2 methylisoborneol) using different organic acids. International Journal of the Bioflux Society 6(6): 511-517.

Japan International Cooperation Agency (JICA). Annual Report. Japan International Cooperation Agency, Japan.

Ji X. \& Verspagen J.M.H., Stomp M. \& Huisman J. (2017). Competition between cyanobacteria and green algae at low versus elevated $\mathrm{CO}_{2}$ : who will win, and why? Journal of Experimental Botany 68(14): 3815-3828. DOI: https://doi.org/10.1093/jxb/erx027

Jiang J., He X. \& Cane D.E. (2007). Biosynthesis of the earthy odorant geosmin by a bifunctional Streptomyces coelicolor enzyme. Nature Chemical Biology 3(11): 711-715.

DOI: https://doi.org/10.1038/nchembio.2007.29

Jüttner F. \& Watson S.B. (2007). Biochemical and ecological control of geosmin and 2-methylisoborneol in source waters. Applied and Environmental Biology 73(14): 43954406. DOI: https://doi.org/10.1128/AEM.02250-06

Klausen C., Jørgensen N., Burford M. \& O’Donohue M. (2004). Actinomycetes may also produce taste and odour. Water 31(5): 586-600.

Klausen C., Nicolaisen M., Strobel B., Warnecke F., Nielsen J. \& Jørgensen N. (2005). Abundance of actinobacteria and production of geosmin and 2-methylisoborneol in Danish streams and fishponds. FEMS Microbiology Ecology 52: 265-278. DOI: https://doi.org/10.1016/j.femsec.2004.11.015

Kim C., Lee S., Hwang S., Cho M., Kim H. \& HongNoh S. (2014). Removal of geosmin and 2-methylisoboneol (2MIB) by membrane system combined with powdered activated carbon (PAC) for drinking water treatment. Journal of Water Process Engineering 4:91-98. DOI: https://doi.org/10.1016/j.jwpe.2014.09.006

Lee G., Kim Y., Kim M. \& Lee M. (2011). Presence, molecular characteristics and geosmin producing ability of actinomycetes isolated from South Korean terrestrial and aquatic environments. Water Science and Technology 63(11): 2745-2751.

DOI: https://doi.org/10.2166/wst.2011.610

Manage P.M. (2013). Training Modules and Guide for Field and Laboratory Studies of Cyanobacteria and Cyanotoxins. Center for Water Quality and Algae Research, University of Sri Jayewardenepura, Nugegoda.

Mcdowall B. (2008). Removal of geosmin and 2- methyl isoborneol from drinking water through biologically active sand filters. PhD thesis. School of chemical Engineering, University of Adelaide, Australia. 
DOI: https://doi.org/10.1504/IJEWM.2007.015685

National Water Supply and Drainage Board (NWSD) (2011). Annual Report. National Water Supply and Drainage Board, Ratmalana, Sri Lanka.

Oh H., Lee C.S., Srivastava A., Oh H. \& Ahn C. (2017). Effects of environmental factors on cyanobacterial production of odorous compounds: geosmin and 2-methylisoborneol. Journal of Microbiology and Biotechnology 27(7): 13161323.

DOI: https://doi.org/10.4014/jmb.1702.02069

Okogwu O.I. \& Ugwumba A.O. (2009). Cyanobacteria abundance and its relationship to water quality in the MidCross River floodplain, Nigeria. International Journal of Tropical Biology 57(1-2): 33-43.

Park T., Yu M., Kim H. \& Cho H. (2014). Characteristics of actinomycetes producing geosmin in Paldang Lake, Korea. Desalination and Water Treatment 57(2):1-12. DOI: https://doi.org/10.1080/19443994.2014.970583

Preecea E. P., Hardyb F. J., Moorec B. C. \& Bryan M. (2017). A review of microcystin detections in estuarine and marine waters: environmental implications and human health risk. Harmful Algae 61: 31-45. DOI: https://doi.org/10.1016/j.hal.2016.11.006

Prescott G.W. (1978). How to Know the Freshwater Phytoplankton, $3^{\text {rd }}$ edition, pp. 348. Cambridge University Press, Cambridge, UK.

Saadoun I.M., Schrader K.K. \& Blevins W.T. (2001). Environmental and nutritional factors affecting geosmin synthesis by Anabaena sp.. Water Research 35(5): 12091218.

DOI: https://doi.org/10.1016/S0043-1354(00)00381-X

Saito K., Okamura K. \& Kataoka H. (2008). Determination of musty odorants, 2 methylisoborneol and geosmin, in environmental water by headspace solid-phase microextraction and gas chromatography-mass spectrometry. Journal of Chromatography A 1186(1-2): 434-437.

DOI: https://doi.org/10.1016/j.chroma.2007.12.078

Sethunge S. \& Manage P.M. (2010). Nuisance algae in water supply projects in Sri Lanka, International Conference on Sustainable Built Environment, Kandy (ICSBE), pp. 62-70.

Shang L., Feng M., Xu X., Liu F., Ke F. \& Li W. (2018). Cooccurrence of microcystins and taste-and-odor compounds in drinking water source and their removal in a full-scale drinking water treatment plant. Toxins 10(1): 26.

DOI: https://doi.org/10.3390/toxins10010026
Sorial G. \& Srinivasan R. (2011). Treatment of taste and odor causing compounds 2-methyl isoborneol and geosmin in drinking water: a critical review. Journal of Environmental Sciences 23(1): 1-13. DOI: https://doi.org/10.1016/S1001-0742(10)60367-1

Tian X. (2013). Study on geosmin degradation by biofilm under enhanced organic and inorganic substrates conditions. PhD thesis, Graduate School of Life and Environmental Sciences, University of Tsukuba, Japan.

US Environmental Protection Agency (USEPA) (2000). Nutrients in the nation's waters: identifying problems and progress. USGS Fact Sheet, pp. 218-296. US Environmental Protection Agency, USA.

Watson S.B., Ridal J. \& Boyer G.L. (2008). Taste and odour and cyanobacterial toxins: impairment, prediction, and management in the Great Lakes. Canadian Journal of Fisheries and Aquatic Sciences 65(8): 1779-1796. DOI: https://doi.org/10.1139/F08-084

World Health Organization (2011). Guidelines for Drinking Water Quality, $4^{\text {th }}$ edition, pp. 28. World Health Organization, Geneva, Switzerland.

World Health Organization (2011). Management of Cyanobacteria in Drinking Water Supplies: Information for Regulators and Water Suppliers. World Health Organization, Geneva, Switzerland.

Yatigammana S.K. \& Perera M.B.U. (2017). Distribution of Cylindrospermopsis raciborskii (Cyanobacteria) in Sri Lanka. Ceylon Journal of Science 46(3): 65-80. DOI: https://doi.org/10.4038/cjs.v46i3.7444

Zamyadi A., Henderson R., Stuetz R., Hofmann R., Ho L. \& Newcombe G. (2015). Fate of geosmin and 2-methylisoborneol in full-scale water treatment plants. Water Research 83: 171-183.

DOI: https://doi.org/10.1016/j.watres.2015.06.038

Zamyadi A., Ho L., Newcombe G., Daly R.I., Burch M., Baker P. \& Prévost M. (2010). Release and oxidation of cell-bound saxitoxins during chlorination of Anabaena circinalis cells. Environmental Science and Technology 44 (23): 90559061.

DOI: https://doi.org/10.1021/es102130b

Zuo Y., Li L., Wu Z. \& Song L. (2009). Isolation, identification and odour-producing abilities of geosmin/2-MIB in actinomycetes from sediments in Lake Lotus, China. Journal of Water Supply: Research and Technology 58(8): 552-561.

DOI: https://doi.org/10.2166/aqua.2009.018 